\title{
Demographic Aspects of Chrysomya megacephala (Diptera, Calliphoridae) Adults Maintained Under Experimental Conditions: Reproductive Rate Estimates
}

\author{
Marcelo Henrique de Carvalho and Claudio José Von Zuben* \\ Departamento de Zoologia; Instituto de Biociências; Universidade Estadual Paulista; Av. 24A, 1515, C. P. 199; \\ 13506-900; Rio Claro - SP - Brasil
}

\begin{abstract}
The objective of this work was to evaluate some aspects of the populational ecology of Chrysomya megacephala, analyzing demographic aspects of adults kept under experimental conditions. Cages of C. megacephala adults were prepared with four different larval densities (100, 200, 400 and 800). For each cage, two tables were made: one with demographic parameters for the life expectancy estimate at the initial age $\left(e_{0}\right)$, and another with the reproductive rate and average reproduction age estimates. Populational parameters such as the intrinsic growth rate $(r)$ and the finite growth rate $(\lambda)$ were calculated as well.
\end{abstract}

Key words: Chrysomya megacephala, Calliphoridae, demographic aspects, reproductive parameters, cohort's mean reproductive age

\section{INTRODUCTION}

In their natural environment, many animal species use discrete and ephemeral substrates for feeding and laying their eggs or larvae. Such substrates consist of separate and small units, such as feces, carcasses, fruits, fungi and decaying plants (Hanski, 1987). Among these species are the blowflies, which procreate mainly on carcasses and feces (Baumgartner and Greenberg, 1984; Guimarães, 1984), where they face severe levels of competition. For blowflies, the larval stage is the main period in which competition for limited food resources occurs. The result of this competition is seen on populational parameters as survival, fecundity and size of the resulting adults, with direct effects on the populational dynamics of the species involved (Von Zuben et al., 2001).
Among the many cases of blowflies, which use discrete and ephemeral substrates for food and egg-laying, the flies of the genus Chrysomya, of the Calliphoridae family are of considerable medical-sanitary importance (Guimarães et al., 1978). They may act as mechanical vectors of human pathogenic microorganisms, cause facultative myiases on animals and humans as well as be used in legal medicine studies as forensic indicators (Zumpt, 1965; Furlanetto et al., 1984; Greenberg, 1991).

In populational ecology studies, it is necessary to investigate, among other factors, the demographic aspects of adults, with direct influence on the populational dynamics of the species involved. One of the ways this kind of study may be done is by making life tables from adult mortality, that is,

\footnotetext{
${ }^{*}$ Author for correspondence
} 
a table of probabilities of events that may occur with animals with distinct attributes (Ebert, 1999). Many demographic studies in insects analyze the mortality pattern of the cohort as a function of time. But fecundity data (offspring produced from egg laying) may be totaled throughout the lifetime of a cohort and considered together with the survival data (Carey, 1993). These procedures enable the calculations of different reproductive rates and together with the survival data in different age groups, determine the cohort's mean reproductive age.

The objective of this study was to analyze demographic aspects of Chrysomya megacephala (Fabricius) adults maintained under experimental conditions, especially those related to reproductive rate estimates. In order to achieve this, a proposal by Carey (1993), which attempted to provide alternative means for combining fecundity and survival data to calculate reproductive rates per generation, was used.

\section{MATERIALS AND METHODS}

\section{Insect rearing}

Cages of adults of the $\mathrm{F}_{1}$ generation of $C$. megacephala were made from the offspring of females captured from natural populations in the Biosciences Institute of UNESP, Campus Rio Claro. To collect these flies, a decaying fish carcass bait was used, and the insects were caught with the help of an insect net. The procedure for keeping adults and immatures in experimental conditions was as follows: adults were kept in screen cages in a room with temperature of $25 \pm$ $1^{\circ} \mathrm{C}, 60 \% \mathrm{RH}$ and $12 \mathrm{~h}$ photoperiod. Water and sugar were provided ad libitum, and macerated bovine liver was supplied during the first seven days after the emergence of the adults in order to allow the development of the gonotrophic cycle of the females (Linhares, 1988). To obtain eggs, flasks with ground beef at the beginning of putrefaction were placed inside the cage with adults. The larvae were kept in flasks with $50 \mathrm{~g}$ of ground beef, considering four larval densities (100, 200, 400 and 800), in temperature-controlled chambers at $25 \pm 1^{\circ} \mathrm{C}$ and $12 \mathrm{~h}$ photoperiod.

Two cages (test and replicate) were made for each density with the adults of the $\mathrm{F}_{2}$ generation of $C$. megacephala. Data on female mortality (number of dead individuals) and fecundity were collected daily. Regarding the fecundity, four identical flasks with the same amount of rotting ground beef were placed on the cages daily at regular time intervals. The presence or absence of eggs and the number of eggs laid were then recorded daily.

\section{Estimate of demographic parameters for $C$. megacephala}

The necessary demographic parameters to make a life table followed the traditional calculation methodology, as described by Krebs (1989), Carey (1993) and Papadopoulos et al (2002).

\section{Estimate of reproductive rates and mean reproduction age for $C$. megacephala}

From the daily mortality data and number of eggs laid, it was possible to estimate reproductive parameters (total fecundity (TF), net fecundity $(\mathrm{NF})$ ), reproductive rates (net reproductive rate $\left(R_{0}\right)$ and average daily egg production (ADP), intrinsic growth rate $(r)$ and finite growth rate $(\lambda)$ ), mean reproduction age of the cohort $(T)$ and population duplication time (DT).

\section{RESULTS AND DISCUSSION}

For each cage, the demographic parameters for the life expectancy at initial age $\left(e_{0}\right)$ estimate were calculated along with the reproductive rates and mean reproduction age estimates for $C$. megacephala. The results obtained for the two cages (test and replicate) for the four larval densities are shown in Table 1. The initial life expectancy values $\left(e_{0}\right)$ obtained for $C$. megacephala females in this study, varied from 39.6 days (cage formed from the density of 800 larvae (replicate)) to 61.83 days for the cage formed from 200 larvae (test). These values were higher than those obtained by Von Zuben et al. (1996) for the same species, which were between 33 and 40 days. A possible explanation for the difference observed between the results of these two studies was that in Von Zuben et al. (1996), the males and females considered were developed on an artificial diet, and the oviposition substrate for the females was not provided.

In this work, the time interval between emergence of females and the beginning of the oviposition process by these flies varied between the $7^{\text {th }}$ and the $8^{\text {th }}$ days. Linhares and Avancini (1989) observed that $100 \%$ of C. megacephala females 
were pregnant within 10 days following their emergence.

Regarding total fecundity (TF) and net fecundity (NF), the greatest values obtained in this study were found at density 100 (replicate), followed by density 200 (test), while the smallest values were found on the cage 800 (replicate). This showed a substantial difference in terms of female fecundity among larval densities (100, 200, 400 and 800) feeding on the same amount of food, that is, larvae competing against each other presented smaller sizes and consequently, lesser fecundity in larger densities. The net fecundity rate values $\left(R_{0}\right)$ obtained for $C$. megacephala were proportionately smaller than those obtained for the fecundity parameters, since the per capita survival probability values are used to calculate $R_{0}$, that is, the individuals which have already died in a certain time interval are disregarded.

Considering the average daily egg production (ADP), the greatest values were found on the cages of density 100 and the smallest were observed for density 800 . These results could be explained by the fact that a greater quantity per capita of food resources in the case of the smaller density, would result in bigger adults with greater fecundity.

Table 1 - Reproductive parameters, rates and mean reproduction age for different densities of C. megacephala, according to Carey (1993) and Papadopoulos et al. (2002).

\begin{tabular}{|c|c|c|c|c|c|c|c|c|c|}
\hline & \multirow[b]{2}{*}{ Formula } & \multicolumn{2}{|c|}{ Larval density 100} & \multicolumn{2}{|c|}{ Larval density 200} & \multicolumn{2}{|c|}{ Larval density 400} & \multicolumn{2}{|c|}{ Larval density 800} \\
\hline & & $\begin{array}{l}\text { Test } \\
\text { cage }\end{array}$ & $\begin{array}{c}\text { Replicat } \\
\text { e cage }\end{array}$ & $\begin{array}{l}\text { Test } \\
\text { cage }\end{array}$ & $\begin{array}{c}\text { Replicat } \\
\text { e cage }\end{array}$ & $\begin{array}{l}\text { Test } \\
\text { cage }\end{array}$ & $\begin{array}{l}\text { Replicat } \\
\text { e cage }\end{array}$ & $\begin{array}{l}\text { Test } \\
\text { cage }\end{array}$ & $\begin{array}{c}\text { Replicate } \\
\text { cage }\end{array}$ \\
\hline$e_{0}$ & $\sum_{x=\alpha}^{\beta} L x$ & 49.5 & 49.22 & 61.83 & 58.15 & 53 & 51.02 & 45.24 & 39.6 \\
\hline $\mathrm{TF}$ & $\sum_{x=\alpha}^{\beta} M_{x}$ & 1759.3 & 3944.06 & 2833.85 & 2085.98 & 2140.96 & 1153.77 & 1286 & 267.44 \\
\hline $\mathrm{NF}$ & $\sum_{x=\alpha}^{\beta} l x M x$ & 1467.74 & 2585.48 & 1455.47 & 1359.54 & 907.89 & 776.83 & 543.9 & 275.61 \\
\hline$R_{0}$ & $\sum_{x=\alpha}^{\beta} l x m x$ & 733.87 & 1292.74 & 727.79 & 679.78 & 453.94 & 307.12 & 271.95 & 137.8 \\
\hline $\mathrm{ADP}$ & $\sum_{x=\alpha}^{\beta} l x M x$ & 29.65 & 52.53 & 23.54 & 23.38 & 17.13 & 15.03 & 12.02 & 6.96 \\
\hline$T$ & $\frac{\sum_{x=\alpha}^{e_{0}}}{\sum_{x=\alpha}^{\beta} l x m x}$ & 31.23 & 36.38 & 46.29 & 39.28 & 39.86 & 34.59 & 35.42 & 34.9 \\
\hline$r$ & $\ln (R o) / T$ & 0.211 & 0.197 & 0.142 & 0.166 & 0.153 & 0.165 & 0.158 & 0.141 \\
\hline$\lambda$ & $e^{r}$ & 1.23 & 1.21 & 1.15 & 1.18 & 1.16 & 1.18 & 1.17 & 1.15 \\
\hline DT & $\ln (2) / r$ & 3.28 & 3.51 & 4.88 & 4.17 & 4.53 & 4.20 & 4.38 & 4.91 \\
\hline
\end{tabular}

$e_{0}$, individual life expectancy at birth; $\alpha$, initial age; $\beta$, age of last individual; $\mathrm{L}_{\mathrm{x}}$, live per capita ratio between the ages $\mathrm{x}$ and $\mathrm{x}+1$; TF, total fecundity; $\mathrm{M}_{\mathrm{x}}$, number of eggs per female at age $\mathrm{x}$; NF, net fecundity; $R_{0}$, net reproductive rate; ADP, average daily egg production; $T$, mean reproduction age of cohort in days; $1 \mathrm{x}$, ratio of surviving individuals at age $\mathrm{x} ; \mathrm{m}_{\mathrm{x}}=\mathrm{M}_{\mathrm{x}} / 2$, number of female progeny produced per female at age $\mathrm{x}$; DT, time, in days, to double the population.

Concerning the mean reproduction age $(T)$, the greatest value obtained was from the cages created from concentrations starting at 200 larvae (test), while the test cage formed from density 100 had the lowest reproduction age. This could be explained by the fact that the initial life 
expectancy for females was higher for cages originated from densities of 200 larvae or more.

Thus, ovipositions by females with greater longevity seemed to have influenced this result, increasing the mean reproduction age in this case. Analyzing the populational growth rate $(r)$ and the population doubling time (DT), it was seen that the growth rate was greater for the population with density 100 , which presented the smallest DT value in days, indicating that a smaller individual density and a greater availability of food for larval development had an effect on viability and fecundity of the resulting adults, allowing a greater and faster population growth in the population of the species studied.

This work corroborated the results of Von Zuben et al. (1993) and Reis et al. (1994), which noted that the fecundity values of $C$. megacephala decreased as larval competition for limited food resources increased, as was the case of $C$. albiceps (Queiroz and Milward-de-Azevedo, 1991). Von Zuben et al. (2000) later studied the effect of different levels of larval aggregation on fecundity and reproductive investment in $C$. megacephala, and they observed that the results of larval competition for food were different in situations where their aggregation level (number of competitors per amount of available food) was the same, but with proportionately different competitor densities and amounts of food. These results indicated that larval competition could depend on the larval aggregation level on the feeding substrate, that, because Goodbrod and Goff (1990) suggested that the larval aggregation of blowflies, with consequent production of proteolytic and salivary enzyme secretions would increase the efficiency of the feeding process, and consequently, accelerated the larval development rate.

More precise estimates of reproductive rates and mean reproductive age, as those obtained in this study could be very useful in understanding the populational dynamics of insects in general (Ebert, 1999) and of this blowfly in particular. Even though bovine liver was not supplied after the first week, the flies might have fed on the ground beef which was made available daily. This way, the females were able to lay eggs throughout their lives, and it was possible that the last eggs came from a second or even third gonotrophic development in a single female (Linhares, 1988). In natural environment, it is very difficult to obtain precise data on reproductive rates. It is important to observe that the combination of survival and fecundity in demographic studies, under experimental conditions, allows a better understanding of the populational growth rate, and supplies a basis for future investigations in the field. This, in turn, facilitates a better understanding of the species' populational dynamics, since a greater female longevity combined with greater fecundity may enable the production of another gonotrophic cycle, and consequently, a larger progeny. This progeny may colonize a greater number of feeding substrates on the environment, enhancing the chances of maintenance of the species (Von Zuben et al., 2001).

\section{ACKNOWLEDGEMENTS}

The authors would like to thank FAPESP, for the financial support (Processes 98/09939-6 and 02/02594-0).

\section{RESUMO}

Chrysomya megacephala (Fabricius) (Diptera, Calliphoridae) é uma espécie de mosca-varejeira de considerável importância médico-sanitária que foi introduzida acidentalmente no Brasil nos anos 70. O objetivo do presente trabalho foi avaliar alguns aspectos da ecologia populacional desta espécie, analisando aspectos demográficos de adultos mantidos sob condições experimentais. Gaiolas de C. megacephala foram montadas com quatro diferentes densidades larvais $(100,200,400$ e 800). Para cada gaiola, foram confeccionadas duas tabelas: uma com parâmetros demográficos para a estimativa da expectativa de vida na idade inicial $\left(e_{0}\right)$, e outra com as estimativas de taxa reprodutiva e idade média de reprodução. Parâmetros populacionais tais como a taxa intrínseca de crescimento $(r)$ e a taxa finita de crescimento $(\lambda)$ foram também calculados.

\section{REFERENCES}

Baumgartner, D. L. and Greenberg, B. (1984), The genus Chrysomya (Diptera: Calliphoridae) in the New World. J. Med. Entomol., 21, 105-113. 
Carey, J. (1993), Applied demography for biologists. Oxford: Oxford University Press.

Ebert, T. A. (1999), Plant and animal populations. Methods in demography. San Diego: Academic Press.

Furlanetto, S. M. P.; Campos, M. L. C.; Hársi, C. M.; Buralli, G. M. and Ishihata, G. K. (1984), Microrganismos enteropatogênicos em moscas africanas pertencentes ao gênero Chrysomya (Diptera: Calliphoridae) no Brasil. Rev. Microbiol., 15, 170-174.

Goodbrod, J. R. and Goff, M. L. (1990), Effects of larval population density on rates of development and interactions between two species of Chrysomya (Diptera: Calliphoridae) in laboratory culture. J. Med. Entomol., 27, 338-343.

Greenberg, B. (1991), Flies as forensic indicators. $J$. Med. Entomol., 28, 565-577.

Guimarães, J. H. (1984), Considerações gerais sobre moscas do gênero Chrysomya no Brasil. Agroquímica (Ciba-Geigy), 24, 8-12.

Guimarães, J. H.; Prado, A. P. and Linhares, A. X. (1978), Three newly introduced blowfly species in Southern Brazil (Diptera: Calliphoridae). Revta. Bras. Ent., 22, 53-60.

Hanski, I. (1987), Nutritional ecology of dung- and carrion-feeding insects. In: Slansky, F. and Rodriguez, F. G. (Eds.). Nutritional ecology of insects, mites, spiders, and related invertebrates. New York: John Wiley and Sons. pp. 837-884.

Krebs, C. J. (1989), Ecological methodology. New York: Harper and Row Publ.

Linhares, A. X. (1988), The gonothrophic cycle of Chrysomya megacephala (Diptera, Calliphoridae) in the laboratory. Rev. Bras. Ent., 32, 383-392.

Linhares, A. X. and Avancini, R. (1989), Ovarian development in the blowflies Chrysomya putoria and Chrysomya megacephala on natural diets. Med. Vet. Entomol., 3, 283-295.

Papadopoulos, N. T.; Katsoyannos, B. I. and Carey, J. R. (2002), Demographic parameters of mediterranean fruit fly (Diptera: Tephritidae) reared in apples. Ann. Entomol. Soc. Amer., 95, 564-569.

Queiroz, M. M. C. and Milward-de-Azevedo, E. M. V. (1991), Técnicas de criação e alguns aspectos da biologia de Chrysomya albiceps (Wiedemann) (Diptera, Calliphoridae), em condições de laboratório. Rev. Bras. Zool., 8, 75-84.

Reis, S. F.; Stangenhaus, G.; Godoy, W. A. C.; Von Zuben, C. J. and Ribeiro, O. B. (1994), Variação em caracteres bionômicos em função de densidade larval em Chrysomya megacephala e Chrysomya putoria (Diptera, Calliphoridae). Rev. Bras. Ent., 38, 33-46.
Von Zuben, C. J.; Reis, S. F.; Do Val, J. B. E.; Godoy, W. A. C. and Ribeiro, O. B. (1993), Dynamics of a mathematical model of Chrysomya megacephala (Diptera: Calliphoridae). J. Med. Entomol., 30, 443-448.

Von Zuben, C. J.; Godoy, W. A. C. and Monteiro Filho, E. L. M. (1996), Curva de sobrevivência e estimativa de entropia em Chrysomya megacephala (Diptera, Calliphoridae). Rev. Bras. Ent., 40, 221-224.

Von Zuben, C. J.; Stangenhaus, G. and Godoy, W. A. C. (2000), Competição larval em Chrysomya megacephala (F.) (Diptera: Calliphoridae): Efeitos de diferentes níveis de agregação larval sobre estimativas de peso, fecundidade e investimento reprodutivo. Rev. Bras. Biol., 60, 195-203.

Von Zuben, C. J.; Von Zuben, F. J. and Godoy, W. A. C. (2001), Larval competition for patchy resources in Chrysomya megacephala (Dipt., Calliphoridae): Implications of the spatial distribution of immatures. J. Appl. Entomol., 125, 537-541.

Zumpt, F. (1965), Myiasis in man and animals in the Old World. London: Butterworths.

Received: August 10, 2004; Revised: April 18, 2005; Accepted: February 15, 2006. 